\title{
KUALITAS SOAL DAN DAYA SERAP TES PENDALAMAN MATERI UN BAHASA INDONESIA SMP DI GUNUNGKIDUL
}

\author{
Susanti Yuni Utami dan Burhan Nurgiyantoro \\ SMP N 5 Panggang Kabupaten Gunungkidul, Universitas Negeri Yogyakarta \\ Email: susanti_yu@yahoo.com/burhan@uny.ac.id
}

\begin{abstract}
ABSTRAK
Penelitian ini bertujuan untuk mendeskripsikan kesesuaian kisi-kisi soal dengan soal, rumusan indikator dengan kompetensi dasar, dan daya serap tiap kompetensi dasar. Penelitian ini merupakan penelitian deskriptif kualitatif-kuantitatif. Subjek penelitian ini kisi-kisi soal, perangkat soal, dan daya serap terhadap soal tes. Teknik pengumpulan data yang digunakan dalam penelitian ini adalah dokumentasi, pembacaan, dan pencatatan. Hasil penelitian ini menunjukkan bahwa soal Tes Pendalaman Materi Ujian Nasional Bahasa Indonesia SMP di Kabupaten Gunungkidul memenuhi aspek materi, konstruksi, dan bahasa. Secara keseluruhan dalam penjabaran 50 indikator pada kisi-kisi soal hanya terdapat satu soal yang tidak sesuai rumusan indikator dengan kompetensi dasarnya. Daya serap untuk peserta didik SMP Negeri di Kabupaten Gunungkidul menunjukkan 23 kompetensi dasar yang masih di bawah capaian 75\%, sedangkan peserta didik SMP swasta di Kabupaten Gunungkidul menunjukkan 29 kompetensi dasar yang masih di bawah capaian 75\%.
\end{abstract}

Kata Kunci: kualitas soal, kisi-kisi, kompetensi dasar, daya serap

\section{THE QUALITY OF TEST QUESTIONS AND STUDENTS' KNOWLEDGE ABSORPTIVE CAPACITY OF MATERIAL INTENSIFICATION TESTS FOR BAHASA INDONESIA NATIONAL EXAMS IN JUNIOR HIGH SCHOOLS IN GUNUNGKIDUL}

\begin{abstract}
ABSTRAK
This research aims at describing the suitability of the specification of the test questions, the indicators and the basic competences, and the knowledge absorptive capacity of each basic competence. This research is a descriptive qualitative-quantitative research. The subjects of the research are the specification of the test questions, the test question set, and the knowledge absorptive capacity of the test questions. The data collection technique used in this research were documenting, reading, and note taking. The research results show that the questions of the material intensification test for Bahasa Indonesia in Junior High schools in Gunungkidul fulfilled the aspects of materials, construction, and language. Of all the 50 indicators, there was only one test question which was not based on the indicators and basic competences. The knowledge absorptive capacity of public junior high school students in Gunungkidul shows that there were 23 basic competences which were still under $75 \%$ of achievements, and for students of private junior high school in Gunungkidul there were 29 basic competences which were still under $75 \%$ of achievements.
\end{abstract}

Keywords: the quality of test questions, the specification, basic competence, knowledge absorptive capacity

\section{PENDAHULUAN}

Undang-Undang No. 20 Tahun 2003

tentang Sistem Pendidikan Nasional Pasal 58 Ayat (2) berisi tentang evaluasi peserta didik, satuan pendidikan, dan program pendidikan dilakukan oleh lembaga mandiri secara berkala, menyeluruh, transparan, dan sistemik untuk menilai pencapaian standar nasional pendidikan. Evaluasi peserta didik dilakukan oleh satuan pendidikan diupayakan untuk mengetahui hasil 
belajar peserta didik pada setiap akhir pendidikan yang ditempuh. Evaluasi ini, bagi guru memberikan informasi sejauh manakah usaha yang telah dilakukannya dalam melakukan proses belajar mengajar. Guru diberi keleluasaan melakukan evaluasi mulai dari perencanaan sampai pelaksanaan, terutama dalam menyusun tes. Baik tidaknya soal tes sangat ditentukan oleh kemampuan guru dalam menyusunnya. Evaluasi yang dilakukan agar sesuai dengan yang diharapkan, maka diperlukan peninjauan kembali terhadap pelaksanaan evaluasi tersebut. Bagi peserta didik, evaluasi tersebut memberikan motivasi kepada mereka untuk memperbaiki, meningkatkan, dan mem-pertahankan prestasinya.

Fokus evaluasi adalah individu, yaitu prestasi belajar yang dicapai kelompok atau kelas. Melalui evaluasi akan diperoleh informasi tentang apa yang telah dicapai dan mana yang belum, dan selanjutnya informasi ini digunakan untuk perbaikan suatu program. Mardapi menjelaskan (2008: 8) evaluasi merupakan salah satu rangkaian kegiatan dalam meningkatkan kualitas, kinerja atau produktivitas suatu lembaga dalam me-laksanakan programnya. Sukardi menambah-kan(2012: 12) evaluasi merupakan bagian dari proses belajar mengajar yang secara keseluruhan tidak dapat dipisahkan dari kegiatan mengajar. Pada sebagian guru masih ada asumsi yang kurang tepat. Misalnya, adalah hal biasa jika kegiatan evaluasi adalah kegiatan yang diharuskan oleh peraturan atau undang-undang.

Mengingat pentingnya evaluasi dalam menentukan kualitas pendidikan, maka upaya merencanakan dan melaksanakan evaluasi hendaknya memperhatikan beberapa prinsip. Menurut Daryanto (2005: 19-21), terdapat beberapa prinsip yang perlu diperhatikan dalam melakukan evaluasi, yaitu keterpaduan, keterampilan siswa, koherensi, pedagogis, dan akuntabilitas.

Berdasar Undang-Undang Nomor 20 Tahun 2003 di atas, pelaksanaan ujian nasional adalah salah satu upaya standardisasi mutu kelulusan peserta didik dalam kerangka peningkatan mutu pendidikan nasional pada umumnya, yang diharapkan dapat berimplikasi pada peningkatan mutu guru dan mutu manajemen persekolahan di masa yang akan datang Ujian nasional yang selanjutnya disebut UN adalah kegiatan pengukuran dan penilaian pencapaian kompetensi lulusan secara nasional pada mata pelajaran tertentu dalam kelompok mata pelajaran ilmu pengetahuan dan teknologi.

Kementerian Pendidikan dan Kebudayaan melalui Badan Standardisasi Nasional Pendidikan (BSNP) mengadakan evaluasi pendidikan yang berupa ujian nasional di setiap jenjang pendidikan pada akhir masa pendidikan. UN memiliki standar kelulusan atau nilai minimal yang harus dicapai agar peserta didik lulus dari pendidikannya. Evaluasi pendidikan ini dibuat secara sistemik untuk mencapai target nilai lulusan yang diharapkan. Ujian Nasional (UN) dan Ujian Sekolah (US) untuk tahun ajaran 2012/2013, kriteria kelulusan peserta didik tertuang di dalam Permendikbud Nomor 3 Tahun 2013 Pasal 6 ayat 2

Pasal di atas menggambarkan posisi alat penilaian khususnya UN dan US dalam proses evaluasi pendidikan. Oleh karena itu, diperlukan kajian tentang soal-soal yang disajikan sebelum tes UN yang sesungguhnya. Berbagai upaya dilakukan oleh satuan pendidikan untuk mencapai standardisasi mutu terutama kelulusan peserta didik.Pelaksanaan ujian nasional pada jenjang pendidikan dasar Sekolah Menengah Pertama dilakukan pada peserta didik kelas IX. Mata pelajaran yang di UN-kan adalah Bahasa Indonesia, Bahasa Inggris, Matematika, dan Ilmu Pengetahuan Alam. Kurikulum Tingkat Satuan Pendidikan (KTSP) pada pembelajaran Bahasa Indonesia menyatakan kegiatan berbahasa mencakup empat aspek keterampilan yaitu mendengar, berbicara, membaca, dan menulis. Keempat aspek itu haruslah diajarkan secara terpadu, bersinergi satu dengan lainnya, seimbang dan saling mendukung. Selain keempat aspek penguasaan keterampilan itu, bahasa juga harus dapat meningkatkan kemampuan siswa dalam bernalar, berpikir, memperluas wawasan serta mampu mendukung kegiatan bersastra.

Sebelum UN dilaksanakan, para guru mempersiapkan peserta didiknya dengan memberikan evaluasi yang berupa tes atau ujian dengan soal yang sesuai Standar Kompetensi Kelulusan (SKL). Tes dibuat oleh kelompok guru, baik di tingkat kabupaten maupun di tingkat provinsi. Kelompok guru ini tergabung dalam 
Musyawarah Guru Mata Pelajaran (MGMP) dan Musyawarah Kelompok Kerja Sekolah (MKKS). MGMP dan MKKS Kabupaten Gunungkidul berperan aktif dalam pembuatan soal Tes Pendalaman Materi untuk soal yang diujikan pada semua kabupaten/kota di Provinsi DIY. Tes dibuat dengan memperhatikan kisi-kisi yang sama dengan kisi-kisi untuk pelaksanaan UN. Pada kenyataannya, menurut pengakuan beberapa guru anggota MGMP Bahasa Indonesia Gunungkidul penulisan kisi-kisi soal tidak ditelaah lebih dulu. Pembuatan perangkat tes tersebut tidak mengikuti langkah-langkah pembuatan tes yang telah ada.

Dengan Tes Pendalaman Materi UN diharapkan peserta didik telah terlatih dengan soal-soal yang serupa ujian nasional. Musyawarah Kelompok Kerja Sekolah (MKKS) SMP Provinsi Daerah Istimewa Yogyakarta membuat suatu bentuk tes yang dinamai Tes Pendalaman Materi Ujian Nasional. Tipe tes sama dengan tipe ujian nasional yakni berupa tes objektif (pilihan ganda). Tes pendalaman materi ujian nasional membantu peserta didik mempersiapkan kematangan mereka dalam memahami materi yang akan diujikan. Hasil tes ini pun dapat dijadikan tolok ukur sampai dimanakah kemampuan mereka dalam kompetensi bahan ajar yang selama ini diterima.

Model penilaian hasil belajar bahasa Indonesia dilakukan oleh pendidik, satuan pendidikan, dan pemerintah. Suryaman menjelaskan, (2012: 169-170) penilaian oleh pemerintah merupakan penilaian akhir pada tingkat satuan pendidikan yang bertujuan untuk menilai pencapaian SKL untuk mata pelajaran bahasa Indonesia. Penilaian oleh pemerintah digunakan untuk menilai pencapaian kompetensi secara nasional.

Kaidah penulisan soal pilihan ganda dalam Depdiknas (2008: 15-16) yakni pada aspek materi, konstruksi, dan bahasa.

Pertama aspek materi, soal harus sesuai dengan indikator (artinya soal harus menanyakan perilaku dan materi yang hendak diukur sesuai dengan rumusan indikator dalam kisi-kisi), pengecoh harus berfungsi, dan setiap soal harus mempunyai satu jawaban yang benar (artinya, satu soal hanya mempunyai satu kunci jawaban).
Kedua, aspek kontruksi yakni, pokok soal harus dirumuskan secara jelas dan tegas. Artinya, kemampuan/ materi yang hendak diukur/ditanyakan harus jelas, tidak menimbulkan pengertian atau penafsiran yang berbeda dari yang dimaksudkan penulis. Setiap butir soal hanya mengandung satu persoalan/gagasan.

Rumusan pokok soal dan pilihan jawaban harus merupakan pernyataan yang diperlukan saja. Artinya apabila terdapat rumusan atau pernyataan yang sebetulnya tidak diperlukan, maka rumusan atau pernyataan itu dihilangkan saja.

Pokok soal jangan memberi petunjuk ke arah jawaban yang benar. Artinya, pada pokok soal jangan sampai terdapat kata, kelompok kata, atau ungkapan yang dapat memberikan petunjuk ke arah jawaban yang benar.

Pokok soal jangan mengandung pernyataan yang bersifat negatif ganda. Artinya, pada pokok soal jangan sampai terdapat dua kata atau lebih yang mengandung arti negatif. Hal ini untuk mencegah terjadinya kesalahan penafsiran peserta didik terhadap arti pernyataan yang dimaksud. Untuk keterampilan bahasa, penggunaan negatif ganda diperbolehkan bila aspek yang akan diukur justru pengertian tentang negatif ganda itu sendiri.

Pilihan jawaban harus homogen dan logis ditinjau dari segi materi. Artinya, semua pilihan jawaban harus berasal dari materi yang sama seperti yang ditanyakan oleh pokok soal, penulisannya harus setara, dan semua pilihan jawaban harus berfungsi.

Pilihan jawaban jangan mengandung pernyataan "Semua pilihan jawaban di atas salah" atau "Semua pilihan jawaban di atas benar". Artinya dengan adanya pilihan jawaban seperti ini, maka secara materi pilihan jawaban berkurang satu karena pernyataan itu bukan merupakan materi yang ditanyakan dan pernyataan itu menjadi tidak homogen.

Panjang rumusan pilihan jawaban harus relatif sama. Kaidah ini diperlukan karena adanya kecenderungan peserta didik memilih jawaban yang paling panjang karena seringkali jawaban yang lebih panjang itu lebih lengkap dan merupakan kunci jawaban.

Pilihan jawaban yang berbentuk angka atau waktu harus disusun berdasarkan urutan 
besar kecilnya nilai angka atau kronologis. Artinya pilihan jawaban yang berbentuk angka harus disusun dari nilai angka paling kecil berurutan sampai nilai angka yang paling besar, dan sebaliknya. Demikian juga pilihan jawaban yang menunjukkan waktu harus disusun secara kronologis. Penyusunan secara unit dimaksudkan untuk memudahkan peserta didik melihat pilihan jawaban.

Gambar, grafik, tabel, diagram, wacana, dan sejenisnya yang terdapat pada soal harus jelas dan berfungsi. Artinya, apa saja yang menyertai suatu soal yang ditanyakan harus jelas, terbaca, dapat dimengerti oleh peserta didik. Apabila soal bisa dijawab tanpa melihat gambar, grafik, tabel atau sejenisnya yang terdapat pada soal, berarti gambar, grafik, atau tabel itu tidak berfungsi.

Rumusan pokok soal tidak menggunakan ungkapan atau kata yang bermakna tidak pasti seperti: sebaiknya, umumnya, kadangkadang.

Butir soal jangan bergantung pada jawaban soal sebelumnya. Ketergantungan pada soal sebelumnya menyebabkan peserta didik yang tidak dapat menjawab benar soal pertama tidak akan dapat menjawab benar soal berikutnya.

Ketiga, pada aspek bahasa, setiap soal harus menggunakan bahasa yang sesuai dengan kaidah bahasa Indonesia. Kaidah bahasa Indonesia dalam penulisan soal di antaranya meliputi: a) pemakaian kalimat: (1) unsur subjek, (2) unsur predikat, (3) anak kalimat; b) pemakaian kata: (1) pilihan kata, (2) penulisan kata, dan c) pemakaian ejaan; (1) penulisan huruf, (2) penggunaan tanda baca. Bahasa yang digunakan harus komunikatif, sehingga pernyataannya mudah dimengerti peserta didik. Pilihan jawaban jangan mengulang kata/frase yang bukan merupakan satu kesatuan pengertian. Letakkan kata/frase pada pokok soal.

Tujuan dari analisis kualitas tes pendalaman materi ujian nasional Bahasa Indonesia SMP ini adalah untuk mengetahui seperti apa kualitas instrumen tersebut, apakah instrumen tersebut telah layak dipakai. Atauapakah instrumen tersebut sudah sesuaidengan syarat-syarat telaah butir soal.

Keberhasilan pembelajaran Bahasa Indonesia tidak bisa terlepas dari adanya evalu- asi yang tepat. Tes pendalaman materi ujian nasional Bahasa Indonesia SMP merupakan salah satu barometer pengukuran keberhasilan pembelajaran Bahasa Indonesia selama menempuh di SMP. Kualitas tes yang digunakan untuk mengetes peserta didik sangat memengaruhi kualitas hasil pengukuran dan juga memengaruhi hasil evaluasi pembelajaran. Dengan kata lain, untuk mendapatkan hasil evaluasi pembelajaran yang baik, tes yang digunakan dalam tes pendalaman materi ujian nasional pun juga harus terjamin kualitasnya. Selama ini, di Kabupaten Gunungkidul tidak dilakukan kajian kualitas tes, sehingga belum diketahui kualitasnya. Tiap indikator soal dengan standar kompetensi dan kompetensi dasar tidak diketahui apakah sudah sesuai. Dengan kualitas tes yang baik, guru dan peserta didik mendapatkan gambaran ketercapaian kompetensi pembelajaran, yakni kemampuan peserta didik, pemetaan mutu pembelajaran, pemetaan daya serap pembelajaran dan upaya perbaikan pada sistem pengajaran dan penilaian.

Tes pendalaman materi ujiannasional Daerah Istimewa Yogyakarta untuk jenjang pendidikan SMP mata pelajaran Bahasa Indonesia dilaksanakan mendekati jadwal ujian nasional. Berdasarkan hasil tes tersebut, daya serap Kabupaten Gunungkidul berada di urutan kelima dari kota dan kabupaten yang ada di Daerah Istimewa Yogyakarta.

Tabel 1. Hasil Tes Pendalaman Materi

\begin{tabular}{clcc}
\hline No. & $\begin{array}{c}\text { Nama } \\
\text { Kota/Kabupaten }\end{array}$ & $\begin{array}{c}\text { Jumlah } \\
\text { Siswa }\end{array}$ & $\begin{array}{c}\text { Nilai } \\
\text { rata-rata } \\
\text { Bahasa } \\
\text { Indonesia }\end{array}$ \\
\hline 1. & Kota Yogya & 7819 & 6,16 \\
2. & Sleman & 13026 & 6,20 \\
3. & Bantul & 10620 & 6,06 \\
4. & Kulonprogo & 6008 & 6,03 \\
5. & Guungkidul & 9344 & 5,94 \\
& Jumlah & 50 & 100 \\
\hline
\end{tabular}

Tabel di atas menunjukkan betapa perlunya strategi yang tepat agar peserta didik di Gunungkidul dapat meningkatkan prestasinya. Tes pendalaman materi sebagai persiapan ujian nasional dikaji pada materi yang dianggap sulit 
oleh peserta didik. Indikator per kemampuan dasar mana saja yang sudah dan yang belum dikuasai peserta didik. Pada intinya, setelah dikaji akan ada umpan balik pembelajaran, kemampuan peserta didik dapat ditingkatkan dan kesulitan peserta didik dapat diatasi. Alat tes berupa tes pendalaman materi perlu ditelaah agar indikator-indikator penulisan tes sesuai dengan standar kompetensi dan kompetensi dasar materi Bahasa Indonesia SMP. Untuk itu, soal-soal tersebut perlu terlebih dahulu dianalisis agar memiliki karakteristik yang sama sehingga benar-benar dapat digunakan untuk mengukur mutu pendidikan. Dalam kenyataannya, tes belum dikaji apakah tes tersebut tersusun atas butir-butir yang baik.

Tes pendalaman materi sebagai persiapan ujian nasional dikaji pada materi yang dianggap sulit oleh peserta didik. Indikator per kemampuan dasar mana saja yang sudah dan yang belum dikuasai peserta didik. Pada intinya, setelah dikaji akan ada umpan balik pembelajaran, kemampuan peserta didik dapat ditingkatkan dan kesulitan peserta didik dapat diatasi.

Kegiatan evaluasi dapat membantu guru memahami kekuatan dan kelemahan yang dialami oleh peserta didik dalam belajar. Semakin berkualitas kegiatan evaluasi pembelajaran, pemahaman guru terhadap peserta didiknya dalam mempelajari materi tertentu semakin baik. Kualitas pembelajaran ditentukan pula oleh kualitas evaluasi dalam proses pembelajaran. Dengan melaksanakan evaluasi yang berkualitas dan menganalisisnya guru memiliki acuan untuk mengambil keputusan yang efektif dalam proses pembelajarannya. Evaluasi juga dapat memberikan informasi pada peserta didik tentang kemajuan belajarnya sehingga peserta didik dapat memperbaiki perilaku belajarnya.

Tes yang berkualitas pada mata pelajaran Bahasa Indonesia sangat dibutuhkan untuk peserta didik kelas IX, agar pendidik benar-benar mengetahui kemampuan dasar peserta didik. Dengan mengetahui kemampuan dasar peserta didik, pendidik akan mendapatkan referensi apakah peserta didik tersebut layak atau tidak untuk melanjutkan ke tingkat selanjutnya.

\section{METODE}

Penelitian ini merupakan penelitian deskriptif kualitatif-kuantitatif, Aspek isi yang dikaji kisi-kisi tes, kesesuaian indikator dengan kisi-kisi soal, dan daya serap. Hal tersebut diperoleh lewat telaah logika, lewat pertimbangan adanya kesejajaran antara soal-soal ujian dan bahan pembelajaran dan kompetensi (indikator) yang akan diukur derajat pencapaiannya. Hal itu dapat diperoleh dengan adanya (i) deskripsi bahan ajar, (ii) kisi-kisi pengujian, dan (iii) telaah butir soal demikian penjelasan Nurgiyantoro (2011:133).

Penelitian ini dilaksanakan di SMP kabupaten Gunungkidul pada bulan Agustus sampai dengan Oktober 2013.Populasi penelitian ini adalah peserta didik yang mengikuti Tes Pendalaman Materi Ujian Nasional Kabupaten Gunungkidul tahun pelajaran 2012/2013. Peserta didik tersebut yakni kelas IX SMP negeri dan swasta di Kabupaten Gunungkidul.

Sampel penelitian ini adalah daya serap peserta didik yang mengikuti Tes Pendalaman Materi Ujian Nasional Bahasa Indonesia SMP di Kabupaten Gunungkidul. Sampel daya serap diambil dari peserta didik yang mengikuti Tes Pendalaman Materi Ujian Nasional Bahasa Indonesia SMP di Kabupaten Gunungkidul. Di Kabupaten Gunungkidul terdapat 105 SMP tersebar di 18 kecamatan, teknik pengambilan sampel sekolah diambil secara proportionate stratifiedrandom sampling. Teknik proportionate digunakan agar sampel yang diambil mewakili jumlah setiap jenis dan tingkatan secara proporsional. Adapun langkah-langkah pengambilan sampel penelitian dengan menggunakan teknik proportionate stratifiedrandom sampling adalah sebagai berikut.

Langkah pertama adalah identifikasi kecamatan yang berada di Kabupaten Gunungkidul. Kecamatan tersebut berjumlah 18 kecamatan. Kedelapan belas kecamatan tersebut diambil sembilan kecamatan.

Berikutnya adalah mengidentifikasi SMP Negeri dan Swasta yang berada di sembilan kecamatan.

Langkah berikutnya adalah penarikan sampel SMP Negeri dan Swasta. Dari sembilan kecamatan diambil 1 SMP Negeri dan 1 SMP Swasta. 
Berikut tabel nama SMP negeri dan swasta di Kabupaten Gunungkidul yang dijadikan sampel.

Tabel 2. Sampel Peserta Didik yang Mengikuti TesPendalaman Materi Ujian Nasional Bahasa Indonesia SMP

\begin{tabular}{ccc}
\hline $\begin{array}{c}\text { Nama } \\
\text { Kecamatan }\end{array}$ & Nama Sekolah & Ket. \\
\hline Wonosari & SMP 4 & Negeri \\
& SMP & Swasta \\
Panggang & SMhammadiyah & \\
& SMP Binamuda & Swasta \\
Playen & SMP 1 & Negeri \\
& SMP & Swasta \\
Nglipar & Muhammadiyah & \\
& SMP 1 & Negeri \\
& SMP & Swasta \\
& Muhammadiyah & \\
Semin & 1 & \\
& SMP 3 & Negeri \\
Semanu & SMP BOPKRI & Swasta \\
& SMP 2 & Negeri \\
Tanjungsari & SMP PGRI & Swasta \\
& SMP 1 & Negeri \\
& SMP & Swasta \\
Monjong & Suhammadiyah & \\
& SMP 3 & Negeri \\
& Muhammadiyah & Swasta \\
Karangmojo & SMP 3 & Negeri \\
& SMP Al Hikmah & Swasta \\
\hline & & \\
\hline & &
\end{tabular}

Instrumen utama dalam penelitian ini adalah peneliti sendiri (intrarater). Data penelitian ini adalah kesesuaian kisi-kisi dengan soal, kesesuaian indikator, dan capaian daya serap. Data tersebut dikumpulkan melalui teknik baca dan catat. Instrumen lain yang digunakan dalam kegiatan pengumpulan data penelitian ialah lembar telaah, check list, dan daya serap. Data hasil penelitian dimintakan pertimbangan kepada expert dan teman sejawat (interater).

Teknik analisis data dalam penelitian ini menggunakan analisis deskriptif kualitatif dan kuantitatif. Analisis deskriptif kualitatif digunakan untuk mengetahui kesesuaian kisi tes dengan perangkat tes dan kesesuaian indikator dengan kompetensi dasar. Analisis deskriptif kuantitatif digunakan untuk mengetahui daya serap peserta didik SMP Kabupaten Gunungkidul pada Tes Pendalaman Materi Ujian Nasional Bahasa Indonesia.

\section{HASIL DAN PEMBAHASAN}

Hasil penelitian ini mendeskripsikan kualitas soal berdasarkan kesesuaian kisi-kisi soal dengan soal, kualitas soal berdasarkan kesesuaian rumusan indikator soal dengan kompetensi dasar, dandaya serap tiap kompetensi dasar peserta didik SMP di Kabupaten Gunungkidul pada mata pelajaran Bahasa Indonesia. Adapun hasil penelitian adalah sebagai berikut.

\section{Kualitas Soal berdasarkan Kesesuaian Kisi-Kisi} Soal dengan Soal

Kesesuaian kisi-kisi soal dengan soal dalam soal Tes Pendalaman Materi Bahasa Indonesia di SMP Kabupaten Gunungkidul dikelompokkan dalam dua skala kategori, yaitu sesuai dan tidak sesuai. Hasil telaah tersebut dapat dilihat dalam Tabel 3.

Tabel 3. Telaah Kisi-Kisi

\begin{tabular}{cccc}
\hline $\begin{array}{c}\text { Nomor } \\
\text { telaah }\end{array}$ & Sesuai & $\begin{array}{c}\text { Tidak } \\
\text { sesuai }\end{array}$ & $\begin{array}{c}\text { Persen- } \\
\text { tase }\end{array}$ \\
\hline 1. & 44 & 6 & 88 \\
2. & 50 & 0 & 100 \\
3. & 50 & 0 & 100 \\
4. & 50 & 0 & 100 \\
5. & 50 & 0 & 100 \\
6. & 50 & 0 & 100 \\
7. & 50 & 0 & 100 \\
8. & 50 & 0 & 100 \\
9. & 49 & 1 & 98 \\
10. & 50 & 0 & 100 \\
11. & 42 & 8 & 84 \\
12. & 50 & 0 & 100 \\
13. & 50 & 0 & 100 \\
14. & 50 & 0 & 100 \\
15. & 50 & 0 & 100 \\
16. & 50 & 0 & 100 \\
17. & 50 & 0 & 100 \\
\multicolumn{2}{c}{ Rata-Rata } & & 98,2 \\
\hline
\end{tabular}

Dari tabel tersebut dapat diketahui bahwa bahwa soal Tes Pendalaman Materi Ujian Nasional Bahasa Indonesia SMP di Kabupaten 
Gunungkidul memiliki validitas isi baik sekali yaitu sebesar 98,2\%. Hal tersebut ditunjukkan bahwa hampir semua aspek kriteria penelaahan terpenuhi oleh butir soal. Maka, dapat disimpulkan bahwa analisis kualitatif menunjukkan bahwa soal Tes Pendalaman Materi Ujian Nasional Bahasa Indonesia SMP di Kabupaten Gunungkidul valid, yakni terpenuhinya tiga tuntutan baik dari segi materi, konstruksi dan bahasa.

Rangkuman hasil telaah kualitas soal, dari 50 butir soal, 38 butir soal memenuhi seluruh aspek (100\%) dalam lembar telaah. Hal itu berarti butir soal tersebut memenuhi seluruh kriteria soal pilihan ganda. Sementara 12 butir soal belum memenuhi 100\% kriteria penelaahan secara keseluruhan.

Kedua belas butir soal yang dinyatakan kurang baik merupakan butir-butir yang tidak memenuhi aspek materi dan konstruksi. Pada aspek materi, yakni butir soal sesuai dengan indikator dan aspek konstruksi, yakni butir soal yang pilihan jawabannya homogen dan panjang pilihan jawaban kurang lebih sama. Butir soal tersebut antara lain 8, 9, 11, 13,19, 24, 25, 34, $37,38,40$, dan 41 . Butir soal yang tidak sesuai dengan indikator, butir soal nomor 24, 25, 34, 38 , 40, dan 41. Butir soal yang pilihan jawabannya tidak homogen dan panjang pilihan jawaban kurang lebih sama, yaitu pada nomor soal 8, 9, 11, 13, 19, 19, 24, 34, dan 37.

Kualitas Soal berdasarkan Kesesuaian Rumusan Indikator dengan Kompetensi Dasar pada Kisi-Kisi Soal

Kesesuaian rumusan indikator dengan kompetensi dasar pada kisi-kisi soal Tes Pendalaman Materi Ujian Nasional Bahasa Indonesia SMP di Kabupaten Gunungkidul dapat dilihat pada Tabel 4.

Berdasarkan kisi-kisi soal Tes Pendalaman Materi Ujian Nasional Bahasa Indonesia SMP di Kabupaten Gunungkidul tahun pelajaran 2012/2013, yang dibuat oleh tim penyusun seperti dijelaskan di atas, teridentifikasi ada indikator kisi-kisi tes yang tidak sesuai dengan kompetensi dasar, yakni pada soal nomor 10 .
Tabel 4. Rangkuman Indikator yang Tidak Sesuai dengan Kompetensi Dasar pada Kisi-Kisi Soal

\begin{tabular}{llrl}
\hline $\begin{array}{c}\text { Kompetensi } \\
\text { Dasar }\end{array}$ & \multicolumn{2}{c}{ Indikator } & $\begin{array}{c}\text { Nomor } \\
\text { Soal }\end{array}$ \\
\hline $\begin{array}{l}\text { 3.2Menemukan } \\
\text { informasi yang } \\
\text { diperlukan }\end{array}$ & $\begin{array}{l}\text { Disajikan } \\
\text { sebuah } \\
\text { siswa data } \\
\text { secara cepat }\end{array}$ & $\begin{array}{l}\text { buku, } \\
\text { dapat }\end{array}$ & \\
dan tepat dari & $\begin{array}{l}\text { penulisan daftar } \\
\text { pustaka yang }\end{array}$ & 10 \\
indeks buku & $\begin{array}{l}\text { pukan } \\
\text { melalui }\end{array}$ & benar. & \\
kegiatan & & & \\
membaca & & & \\
memindai & & & \\
\hline
\end{tabular}

Daya Serap per Indikator per Kemampuan Dasar Peserta Didik SMP di Kabupaten Gunungkidul

Hasil uji alat tes memberikan data empirik untuk keperluan berbagai analisis kuantitatif untuk menilai kualitas alat tes yang bersangkutan dan atau melakukan tindak lanjut penilaian. Analisis kuantitatif yang dimaksud bermacam-macam yang pelaksanaannya tergantung kebutuhan, dan beberapa di antaranya adalah analisis butir soal dan analisis jawaban per indikator (Nurgiyantoro, 2012, p.26). Pada penelitian ini adalah analisis jawaban butir soal per indikator per kemampuan dasar dipergunakan sebagai masukan umpan balik pembelajaran dan mengembangkan program remedial. Daya serap per indikator per kemampuan dasar peserta didik SMP di Kabupaten Gunungkidul pada Tes Pendalaman Materi Ujian Nasional Bahasa Indonesia, sampel yang diambil adalah 18 SMP yang terdiri atas 9 SMP negeri dan 9 SMP swasta. SMP tersebut mewakili tiap kecamatan yang ada di Kabupaten Gunungkidul.

Analisis jawaban tidak lain adalah telaah hasil pengukuran per indikator per kompetensi dasar yang dilakukan dengan menghitung jawaban benar dan salah peserta didik untuk seluruh butir soal yang diujikan. Sebuah indikator dan kompetensi dasar dinyatakan dikuasai oleh peserta didik jika tingkat penguasaannya minimal $75 \%$. Hasil pemindaian lembar jawab peserta didik yang mengikuti Tes Pendalaman Materi Ujian Nasional Bahasa Indonesia dan proses analisis butir soal menggunakan program $M S$ 
Excel menjadi bahan analisis daya serap peserta didik pada penguasaan materi yang diujikan.

Mardapi menjelaskan (2008: 143), butir soal yang dipakai dalam ujian tidak boleh terlalu sukar atau terlalu mudah, sehingga kisaran indeks kesukarannya adalah 0,3 sampai 0,7 . Butir soal yang memiliki tingkat kesulitan di bawah 0,3 dianggap terlalu sulit dan butir soal yang memiliki tingkat kesulitan di atas 0,7 dianggap terlalu mudah. Hasil analisis daya serap dan tingkat kesukaran dapat dilihat pada Tabel5.

Tabel 5. Rata-Rata Persentase Tingkat Kesukaran Butir Soal pada Jawaban Peserta Didik SMP Negeri

\begin{tabular}{clc}
\hline No. & Tingkat Kesukaran & Persentase \\
\hline 1. & Mudah & 54,44 \\
2. & Sedang & 40,89 \\
3. & Sukar & 4,67 \\
\hline
\end{tabular}

Berdasarkan tabel 5 dapat diketahui bahwa sebanyak $54,44 \%$ butir soal bagi peserta didik SMP negeri tingkat kesukarannya mudah, sedangkan $40,89 \%$ sedang dan $4,67 \%$ adalah sukar. Berikut rata-rata persentase tingkat kesukaran butir soal pada jawaban peserta didik SMP swasta.

Tabel 6. Rata-Rata Persentase Tingkat Kesukaran Butir Soal pada Jawaban Peserta Didik SMP Swasta

\begin{tabular}{clc}
\hline No. & Tingkat Kesukaran & Persentase \\
\hline 1. & Mudah & 37,11 \\
2. & Sedang & 49,33 \\
3. & Sukar & 13,56 \\
\hline
\end{tabular}

Nurgiyantoro menjelaskan (2012, p. 22) penelaahan butir soal dapat disebut juga sebagai telaah kualitatif-redaksional. Kegiatan ini mengandalkan pertimbangan logika, baik yang menyangkut logika keilmuan (materi), logika penyusunan butir soal (konstruksi), maupun cara membahasakan soal (bahasa). Kaidah penulisan soal pilihan ganda mencakup tiga aspek,yaitumateri, konstruksi, dan bahasa.

Berdasarkan hasil telaah soal yang dilakukan, dapat diketahui bahwa soal Tes
Pendalaman Materi Ujian Nasional Bahasa Indonesia SMP di Kabupaten Gunungkidul memiliki validitas isi baik sekali yaitu sebesar $98,2 \%$. Hal tersebut menunjukkan bahwa kualitas isi soal sangat baik karena hampir semua aspek kriteria penelaahan terpenuhi oleh butir soal.Maka, dapat disimpulkan bahwa analisis kualitatif menunjukkan bahwa soal Tes Pendalaman Materi Ujian Nasional Bahasa Indonesia SMP di Kabupaten Gunungkidul valid, yakni terpenuhinya tiga tuntutan baik dari segi materi, konstruksi dan bahasa.

Pada aspek materi dan konstruksi yang belum memenuhi persyaratan sebagai berikut. Pada aspek materi terdapat 6 butir soal yang tidak memenuhi kriteria nomor 01 (butir soal sesuai dengan indikator) yaitu butir nomor 24 , $25,34,38,40,41$. Pada aspek konstruksi terdapat 9 butir soal yang tidak memenuhi kriteria nomor 09 (Pilihan jawaban homogen) dan 11 (Panjang pilihan jawaban kurang lebih sama), yaitu nomor $8,9,11,13,19,24,34,37$. Berikut butir soal yang tidak memunyai ketidaksesuaian dengan kriteria penelaahan butir soal pilihan ganda, pada kriteria nomor 01 (butir soal sesuai dengan indikator) yaitu butir nomor 24 .

Pada soal nomor 24 berisi tentang materi penulisan catatan harian, sedangkan pada kisi-kisi soal tes, indikator soal berisi disajikan sebuah penggalan drama, siswa dapat menentukan latar tempat dan waktu teks drama. Selanjutnya pada indikator soal nomor 25 berisi disajikan sebuah ilustrasi, siswa dapat menentukan kalimat catatan harian sesuai konteks tetapi pada soal ditanyakan latar waktu dan tempat dalam kutipan drama.

Pada kisi-kisi soal tes, indikator nomor soal 34 berisi disajikan sebuah gambar, siswa dapat menentukan paragraf teks berita sesuai gambar tersebut. Kenyataannya, soal nomor 34 tidak disertai gambar. Soal nomor 38 indikator dalam kisi-kisi soal nomor 38 berisi disajikan sebuah kalimat, siswa dapat menyunting penulisan huruf kapital kalimat tersebut, sedangkan pada soal di atas berisi tentang penggunaan tanda baca titik pada paragraf. Kemudian indikator dalam kisi-kisi soal nomor 40 adalah disajikan kalimat tidak efektif, siswa dapat menyunting kalimat tidak efektif tersebut. Pada kisi-kisi soal nomor 
41, indikator berisi disajikan sebuah ilustrasi, siswa dapat menentukan paragraf bagian isi teks pidato sesuai konteks tersebut. Pada butir soal di atas tidak sesuai dengan indikator.

Pada aspek konstruksi yakni kriteria nomor 09 (pilihan jawaban homogen) dan 11 (panjang pilihan jawaban kurang lebih sama) terjadi pada soal 19 yakni, jawaban A, B, C, dan D tidak homogen. Pilihan A dan $\mathrm{C}$ yang homogen sedangkan $\mathrm{B}$ dan $\mathrm{D}$ tidak.Akan lebih baik apabila pilihan jawaban $B$ dan $D$ juga homogen dengan pilihan jawaban A dan $\mathrm{C}$.

Kriteria no 11 (panjang pilihan jawaban kurang lebih sama), lihat butir soal pada Lampiran yakni soal tes tersebut yakni pada nomor 8 , $9,11,13,19,24,34$, dan 37. Butir soal ditulis dengan panjang pilihan jawaban tidak sama.

Nurgiyantoro menambahkan(2012, p. 21) pengembangan alat pengujian harus mengukur semua kompetensi dasar yang tercermin dalam bahan ajar dan indikator secara proporsional terhadap semua kompetensi dasar yang diujikan. Agar kegiatan pengembangan dapat dilakukan dengan baik dan dapat dipertanggungjawabkan, pembuatan butir-butir soal (pertanyaan) harus mendasarkan diri pada kisi-kisi yang sengaja dirancang untuk maksud itu. Kisi-kisi itulah yang harus dijadikan acuan menulis butir-butir soal.

Berdasarkan kisi-kisi soal Tes Pendalaman Materi Ujian Nasional Bahasa Indonesia SMP di Kabupaten Gunungkidul tahun pelajaran 2012/2013, yang dibuat oleh tim penyusun seperti dijelaskan di atas, teridentifikasi ada indikator kisi-kisi tes yang tidak sesuai dengan kompetensi dasar, yakni pada soal nomor 10 .

Pada soal nomor 10, kompetensi dasar berisi menemukan informasi yang diperlukan secara tepat dari indeks buku melalui kegiatan membaca memindai. Tetapi pada indikator pada soal nomor 10 tercantum disajikan data sebuah buku, siswa dapat menentukan penulisan daftar pustaka yang benar. Hal ini jelas tidak sesuai.

Analisis jawaban adalah telaah hasil pengukuran per indikator per kompetensi dasar yang dilakukan dengan menghitung jawaban benar dan salah peserta didik untuk seluruh butir soal yang diujikan. Sebuah indikator dan kompetensi dasar dinyatakan dikuasai oleh peserta didik jika tingkat penguasaannya minimal 75\%. Indikator-indikator tertentu dari kemampuan-kemampuan dasar tertentu yang masih rendah tingkat ketercapaiannya haruslah kembali "dibelajarkan" lewat program remedial. Peserta didik yang tingkat pencapaiannya masih di bawah standar minimal harus diberi program remedial, sedang yang sudah memenuhi diberi program pengayaan demikian penjelasan Nurgiyantoro (2011,p.135).

Salah satu program remedial adalah memberikan umpan balik (feed-back) kepada semua pihak yang terlibat dalam pembelajaran, baik secara langsung maupun tidak langsung. Hasil pemindaian lembar jawab peserta didik yang mengikuti Tes Pendalaman Materi Ujian Nasional Bahasa Indonesia menjadi bahan analisis daya serap peserta didik. Daya serap untuk peserta didik SMP negeri di Kabupaten Gunungkidul yang mengikuti Tes Pendalaman Materi menunjukkan 23 kompetensi dasar yang masih di bawah capaian $75 \%$.

Daya serap untuk peserta didik SMP swasta di Kabupaten Gunungkidul yang mengikuti Tes Pendalaman Materi menunjukkan 29 kompetensi dasar yang masih di bawah capaian $75 \%$.

Rangkuman hasil daya serap penguasaan materi pada masing-masing SMP Negeri dan SMP Swasta di Kabupaten Gunungkidul menunjukkan untuk SMP Negeri rata-rata daya serapnya adalah 69,38\% dan SMP Swasta rata-rata daya serapnya adalah $62,56 \%$. Hal ini menunjukkan penguasaan materi baik SMP Negeri maupun SMP Swasta di Kabupaten Gunungkidul masih kurang. Kemampuan peserta didik pada kompetensi dasar yang diujikan masih di bawah $75 \%$.

Miller et.al (2009: 130) menjelaskan sebagai berikut.

Classroom tests and assessments play a central role in the evaluatioan of student learning. They provide relevant measures of many important learning outcomes and indirect evidence concerning others.

Tes dan penilaian mempunyai peran yang utama pada proses pembelajaran. Penilaian ini penting untuk mengetahui daya serap peserta 
didik terhadap materi yang dipelajari. Jika diamati pada kompetensi yang diujikan daya serap yang dimiliki setiap sekolah berbeda-beda, sehingga perlu dicermati kompetensi-kompetensi yang masih kurang nilainya agar dapat dilakukan upaya perbaikan sistem pengajaran. Prestasi belajar peserta didik dapat pula diketahui dari daya serap terhadap pembelajaran yang dilakukan. Hal itu tersebut sejalan dengan yang diungkapkan oleh Nitko \& Brookkhart (2011: 497) "Achievement is knowledge, skills, and abilities that students have developed as a result of instruction." Prestasi adalah pengetahuan, keterampilan, dan kemampuan siswa yang telah berkembang sebagai hasil dari instruksi. Dengan demikian dapat diketahui kompetensi dasar yang dikuasai dan belum dikuasai oleh peserta didik dalam menghadapi Tes Pendalaman Materi Ujian Nasional Bahasa Indonesia di Kabupaten Gunungkidul tahun pelajaran 2012/2013. Nilai dari Tes Pendalaman Materi Ujian Nasional Bahasa Indonesia di Kabupaten Gunungkidul ini merupakan gambaran penguasaan kompetensi yang dipelajari siswa selama menempuh di Sekolah Menengah Pertama, sehingga diperlukan soal yang berkualitas baik.

BSNP (2012) menyebutkan sekolah juga dapat menggunakan analisis daya serap untuk mengetahui kelemahan-kelemahan pada tes setara Ujian Nasional sebelumnya. Dengan pemetaan kelemahan-kelemahan yang ada pada peserta didik, sekolah diharapkan melakukan perbaikan pada materi yang menjadi kelemahan peserta didik. Untuk mendapatkan soal yang berkualitas maka harus dilakukan langkah pengembangan soal yang sesuai standar agar dapat mengevaluasi secara tepat apa yang akan diukur.

\section{SIMPULAN}

Berdasarkan kajian teori, hasil penelitian, dan pembahasan dapat diperoleh simpulan sebagai berikut. (1) Hasil penelitian menunjukkan bahwa soal Tes Pendalaman Materi Ujian Nasional Bahasa Indonesia SMP di Kabupaten Gunungkidul memiliki validitas isi baik sekali yaitu sebesar $98,2 \%$. Kualitas isi soal sangat baik karena hampir semua aspek kriteria penelaahan terpenuhi oleh butir soal. Maka, dapat disimpulkan bahwa analisis kualitatif menunjuk- kan bahwa soal Tes Pendalaman Materi Ujian Nasional Bahasa Indonesia SMP di Kabupaten Gunungkidul valid,yakni terpenuhinya tiga tuntutan baik dari segi materi, konstruksi dan bahasa.

Secara keseluruhan dalam penjabaran 50 indikator pada kisi-kisi soal Tes Pendalaman Materi Ujian Nasional Bahasa Indonesia SMP di Kabupaten Gunungkidul tahun pelajaran $2012 / 2013$, terdapat $99 \%$ soal sesuai rumusan indikator dengan kompetensi dasarnya, sedangkan $1 \%$ belum sesuai. (3) Daya serap untuk peserta didik SMP Negeri di Kabupaten Gunungkidul yang mengikuti Tes Pendalaman Materi menunjukkan 23 kompetensi dasar yang masih di bawah capaian $75 \%$. Daya serap untuk peserta didik SMP swasta di Kabupaten Gunungkidul yang mengikuti Tes Pendalaman Materi menunjukkan 29 kompetensi dasar yang masih di bawah capaian $75 \%$.

\section{Ucapan Terima Kasih}

Artikel ini disusun berdasarkan tesis yang telah diujikan dan direvisi. Oleh karena itu, saya mengucapkan terima kasih kepada pembimbing Prof. Dr. Burhan Nurgiyantoro dan dewan penguji tesis yang telah memberi masukkan dan saran terhadap tesis saya. Dengan bantuan tersebut artikel hasil penelitian ini dapat diwujudkan.

\section{DAFTAR PUSTAKA}

Daryanto, H. 2005. Evaluasi Pendidikan. Jakarta: Rineka Cipta

Depdiknas. 2008. Panduan Penulisan Butir Soal. Jakarta: Direktorat Pembinaan Sekolah Menengah Atas.

Mardapi, D. 2008. Teknik Penyusunan Instrumen Tes dan Nontes. Yogyakarta: Mitra Cendikia.

Miller, M.D., Linn, R.L., \& Gronlund, N.E 2009. Measurement and Assessment in Teaching $\left(10^{\text {th }}\right.$ ed). New Jersey: Pearson.

Nitko, A.J. \& Brookhart, S.M. 2011. Educational Assessment of Students. Boston: Allyn \& Bacon.

Nurgiyantoro, B. 2011. Penilaian Otentik dalam Pembelajaran Bahasa. Yogyakarta: Gadjah Mada University Press. 
2012. Penilaian Pembelajaran Bahasa Berbasis Kompetensi. Yogyakarta: BPFE-Yogyakarta.
Sukardi. 2012. Evaluasi Pendidikan. Jakarta: Bumi Aksara.

Suryaman, M. 2012. Metodologi Pembelajaran Bahasa. Yogyakarta: UNY Press. 